\title{
Effect Of Fertilization On Available Cadmium Level In Soil And Lettuce
}

\author{
Ljiljana Bošković-Rakočević, R. Pavlović \\ University of Kragujevac, Faculty of Agronomy, Cacak, Serbia \\ Darinka Bogdanović \\ University of Novi Sad, Faculty of Agriculture, Novi Sad, Serbia
}

\begin{abstract}
The objective of this study was to evaluate the effect of organic fertilizer (cattle manure) and monoammonium phosphate (Russian MAP-R and Serbian MAP-S) on available Cd levels in soil and Cd uptake by lettuce plants grown on vertisol and fluvisol. Fertilization treatments were as follows: control - without fertilization, mature cattle manure (20 g kg${ }^{-1}$ soil), MAP-R ( $0.1 \mathrm{~g} \mathrm{~kg}^{-1}$ soil), MAP-S $\left(0.1 \mathrm{~g} \mathrm{~kg}^{-1}\right.$ soil). Prior to the experiment, available $\mathrm{Cd}$ level was higher in vertisol $\left(0.06 \mathrm{mg} \mathrm{kg}^{-1}\right)$ than in fluvisol $(0.04$ $\mathrm{mg} \mathrm{kg}^{-1}$ ). The manure application had no significant effect on increased DTPAextractable $\mathrm{Cd}$ content in both soils, as compared to control. Available Cd level was decreased by MAP-R (vertisol $0.0494 \mathrm{mg} \mathrm{kg}^{-1}$, fluvisol $0.0227 \mathrm{mg} \mathrm{kg}^{-1}$ ) and increased by MAP-S application (vertisol $0.0577 \mathrm{mg} \mathrm{kg}^{-1}$, fluvisol $0.0288 \mathrm{mg} \mathrm{kg}^{-1}$ ) in both soil types as compared to control. The use of manure and MAP increased Cd concentration in lettuce, in all treatments except in manure treatment on vertisol. Lettuce head weight was highest in manure treatment on both soil types.
\end{abstract}

Key words: DTPA-extractable Cd, manure, phosphorus fertilizers, fluvisol, vertisol. 


\section{Introduction}

Soil pollution with heavy metals $(\mathrm{Cd}, \mathrm{Pb}, \mathrm{Zn}, \mathrm{Cr}, \mathrm{Ni})$ is a large problem in intensive plant production. Major sources of heavy metals in soils include the parent material and phosphorus fertilizers as one of the most important anthropogenic sources of soil pollution with heavy metals, $\mathrm{Cd}$ in particular (Bogdanovic et al. 1999; Jiao et al. 2004; Chen et al. 2009; Williams and David 1973). Williams and David (1973) report the Cd content of superphosphate of 38$40 \mathrm{mg} \mathrm{kg}^{-1}$, Bogdanovic et al. (1999) applied superphosphate containing 2.08-7.50 $\mathrm{mg} \mathrm{kg}$, whereas Cd level in MAP was $144 \mathrm{mg} \mathrm{kg}^{-1}$ (Jiao et al. 2004). The use of phosphorus-based fertilizers leads to increased soil Cd levels, thereby affecting $\mathrm{Cd}$ uptake by plants (Fontes et al. 2008). Manure applications increase soil Cd levels, having a long-term effect (Benke et al. 2008). Both the uptake and level of $\mathrm{Cd}$ are dependent upon soil type, primarily acidity, organic matter content, soil texture (Golia et al. 2008; Williams and David 1973). Plants have the ability to accumulate different amounts of $\mathrm{Cd}$ in edible parts, without causing an unfavorable effect on their growth (Chen et al. 2009). Singh (1990) obtained an increase in Cd levels in test plants with increasing phosphorus rates.

Lettuce (Lactuca sativa L.) is a leafy vegetable crop that shows affinity to accumulate Cd. Cadmium uptake from soil is higher in lettuce than in potatoes and tomatoes (Singh 1990), whereas no such differences were detected as compared to spinach (Sani et al. 2011).

Results of previous research on the effect of $\mathrm{Cd}$ on crop yield show differences. He and Singh (1994) reported that crop yield is generally not dependent upon fertilization and different soil Cd levels. Maclean (1976) found a decrease in lettuce yield as induced by an application rate of $5 \mathrm{mg} \mathrm{kg}^{-1}$, whereas Moustakas et al. (2001) and Kavvadias et al. (2012) observed that Cd rates higher than $10 \mathrm{mg} \mathrm{kg}^{-1}$ result in decreasing lettuce yield. John et al. (2008) determined that the negative effect of increasing $\mathrm{Cd}$ rates on the fresh weight of lettuce is manifested in reduced root growth, as confirmed by Zheng et al. (2010).

The objective of this study was to evaluate the effect of manure and different types of phosphorus fertilizers applied to two types of soil on soil $\mathrm{Cd}$ level and $\mathrm{Cd}$ availability to lettuce.

\section{Materials and methods}

\section{Plant material and field trial}

The experiment was conducted in pots in greenhouses at the trial field of the Faculty of Agronomy at Trbušani near Čačak, Western Serbia $\left(43^{\circ} 55^{\prime} \mathrm{N}\right.$, latitude; $20^{\circ} 19^{\prime} \mathrm{E}$ longitude; $255 \mathrm{~m}$ altitude). The research involved two soil types, including fluvisol and vertisol (Table 1). Each pot was filled with $3 \mathrm{~kg}$ air-dry soil sampled 
from a 0-30 $\mathrm{cm}$ layer and sieved through $4 \mathrm{~mm}$ sieve. In general, soil conditions were good for normal vegetative growth of lettuce, as previously reported (Fallovo et al., 2009).

Table 1- Chemical properties of soils

\begin{tabular}{lcccccc}
\hline Soil type & $\mathbf{p H} / \mathbf{K C l} \mathbf{l}$ & $\begin{array}{c}\text { Organic } \\
\text { matter } \\
(\mathbf{\%})\end{array}$ & $\begin{array}{c}\text { Total } \\
\mathbf{N}(\mathbf{\%})\end{array}$ & $\begin{array}{c}\text { Available } \\
\mathbf{p h o s p h o r u s} \\
\left(\mathbf{m g ~ 1 0 0 ~}^{-1}\right)\end{array}$ & $\begin{array}{c}\text { Available } \\
\text { potassium } \\
\left(\mathbf{m g ~ 1 0 0 g}^{-1}\right)\end{array}$ & $\begin{array}{c}\text { Available } \\
\mathbf{C d} \\
\left(\mathbf{m g ~ k g}^{-\mathbf{1}}\right)\end{array}$ \\
\hline Fluvisol & 6.9 & 3.03 & 0.16 & 35.0 & 63.2 & 0.04 \\
Vertisol & 6.9 & 4.56 & 0.25 & 51.6 & 89.5 & 0.06 \\
\hline
\end{tabular}

The experiment involved fertilization with organic fertilizer- manure and mineral fertilization with two MAP (monoammonium phosphate-11\%N, $52 \%$ $\mathrm{P}_{2} \mathrm{O}_{5}$ ) products, one manufactured in Serbia (MAP-S), the other in Russia (MAPR) (Table 2). The composition of organic fertilizers-cattle manure, which was used in the experiment was as follows: $\mathrm{N}_{\mathrm{TOT}}-0.5 \%, \mathrm{P}_{2} 0_{5}-0.3 \%, \mathrm{~K}_{2} 0-0.6 \%$, organic matter- $25 \%, \mathrm{C}: \mathrm{N}$ ratio-18:1. In order to improve the fertility of the soil used for lettuce production, nitrogen $\left(0.15 \mathrm{~g} \mathrm{~kg}^{-1}\right.$ soil) as CAN (calcium ammonium nitrate, containing $27 \%$ of $\left.\mathrm{N}_{\mathrm{TOT}}\right)$, and potassium $\left(0.1 \mathrm{~g} \mathrm{~kg}^{-1}\right.$ soil) as $\mathrm{KCl}$ (potassium chloride, containing $60 \%$ of $\mathrm{K}_{2} \mathrm{O}$ ) were incorporated into the soil.

Table 2 - Cd content of fertilizers

\begin{tabular}{ll}
\hline Fertilizer & $\mathbf{C d}$ content $\left(\mathbf{m g ~ k g}^{-\mathbf{1}}\right)$ \\
\hline Mature cattle manure & 0.53 \\
MAP-R & 0.34 \\
MAP-S & 12.32 \\
\hline
\end{tabular}

Fertilization treatments were as follows: control - without fertilization, mature cattle manure - $20 \mathrm{~g} \mathrm{~kg}^{-1}$ soil, MAP-R - $0.1 \mathrm{~g} \mathrm{~kg}^{-1}$ soil, MAP-S $-0.1 \mathrm{~g} \mathrm{~kg}^{-}$ ${ }^{1}$ soil.

The material used in the experiment was lettuce (Lactuca sativa L.), dutch butterhead cultivar Sunstar. A single young transplant was planted per container in three replications per treatment. During planting, the plants were watered until field moisture capacity was reached, with subsequent watering treatments being employed at soil moisture below $70 \%$ of the field capacity.

\section{Chemical analysis}

Soil samples were analyzed using standard methods, as follows: $\mathrm{pH}$ in $1 \mathrm{M}$ $\mathrm{KCl}$ - electrometric method; organic matter was determined by the WalkleyBlack's procedure (Nelson and Sommers 1982); total N was determined by 
Kjeldahl analysis (Gerhardt Vapodest); available phosphorus and potassium extraction with $0.1 \mathrm{M} \mathrm{NH}_{4}$-lactate and $0.4 \mathrm{M} \mathrm{CH}_{3} \mathrm{COOH}$, according to EgnerRiehm ( $\mathrm{P}$ was analyzed spectrophotometrically by the phospho-vanadate colorimetric method (Hewlett Packard 8452A); K was determined by flame photometry (Flapho 4, Carl Zeiss, Jena); available Cd - diethylenetriamine pentaacetic acid (DTPA) extraction of the Cd involved shaking $5.0 \mathrm{~g}$ of soil for 2 $\mathrm{h}$ with $25 \mathrm{ml}$ of a solution containing $0.005 \mathrm{~mol} \mathrm{~L}-1 \mathrm{DTPA} 0.01 \mathrm{~mol} \mathrm{~L}-1 \mathrm{CaCl}_{2}$, and 0.1 mol L-1TEA (triethanolamine) buffered at $\mathrm{pH} 7.3$ (Lindsay and Norvell 1978) and analyzed using atomic absorption spectroscopy (Perkin-Elmer, 3300/96, MHS-10)

After harvest, the plant materials were washed, dried, weighed and ground for analysis. For plant samples, $0.5 \mathrm{~g}$ of dried samples was digested with $\mathrm{HNO}_{3}$ and $\mathrm{HClO}_{4}$ in a 5:1 ratio until a transparent solution was obtained (Allen, 1989) and analyzed using atomic absorption spectrophotometry (Perkin-Elmer, 3300/96, MHS-10).

\section{Statistical analysis}

All data in the present study were subjected to analysis of variance (ANOVA) and means were separated by LSD test at $P \leq 0.05$ using the MSTATC statistical computer package (Michigan State University, East Lansing, MI, USA).

\section{Results and Discussion}

\section{Available Cd in the soil}

Prior to the experiment, the level of available Cd in fluvisol was $0.04 \mathrm{mg} \mathrm{kg}^{-1}$ (Table 1). After the lettuce growing cycle, the $\mathrm{Cd}$ level decreased in all treatments (Figure 1), ranging from $0.0227 \mathrm{mg} \mathrm{kg}^{-1}$ (MAP-R) to $0.0288 \mathrm{mg} \mathrm{kg}^{-1}$ (MAP-S and manure). The same decreasing tendency of available Cd levels was also observed in vertisol (Figure 1), falling within the range of $0.06 \mathrm{mg} \mathrm{kg}^{-1}$ before planting to $0.0494 \mathrm{mg} \mathrm{kg}^{-1}$ (MAP-R) and $0.0577 \mathrm{mg} \mathrm{kg}^{-1}$ (MAP-S) after harvest. The measured decrease in available Cd levels in the soil after lettuce harvest suggests the uptake of $\mathrm{Cd}$ accumulated in plant tops through the root system during the growing season. The low level of available $\mathrm{Cd}$ found in both soil types before the experiment was the result of their low natural supply of this element and neutral soil reaction $(\mathrm{pH}$ 6.9) which directly induced a reduction in available Cd levels in the soil (He and Singh 1994). Cd levels showed high significant differences between the test soils (Table 3), with the higher level being determined in vertisol, the type of loamy soils. The adsorption complex of these soils contains mineral clays which have a higher ion adsorption capacity as 
compared to fluvisol, thereby contributing to an increased content of available $\mathrm{Cd}$ in the soil. Moreover, vertisol is the type of soil richer in organic matter. Maclean (1976) found that the content of available Cd increases in soils having a larger amount of organic matter, as confirmed in this study.

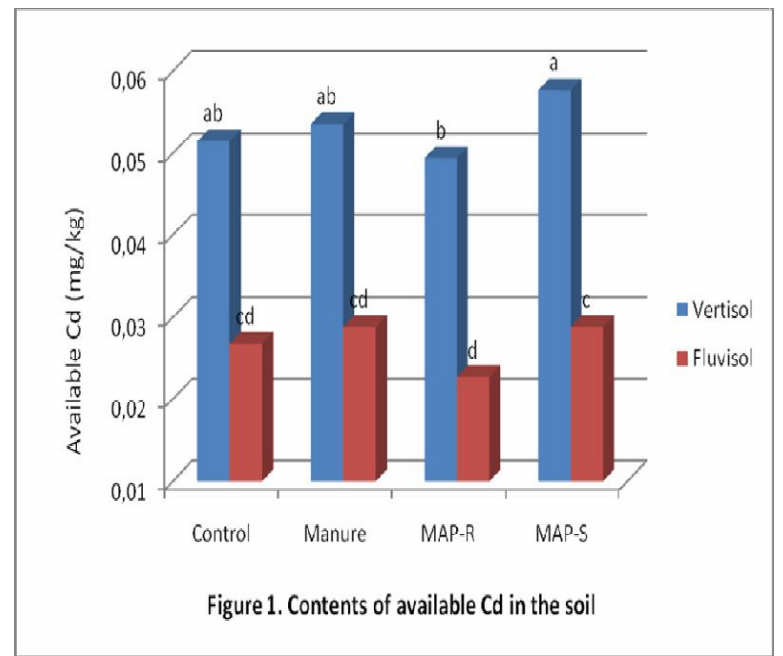

*The same letters indicate non-significant differences among means at $\mathrm{P} \leq 0.05$ by LSD test

The use of MAP-R resulted in decreased Cd levels in both soil types than in the control (Figure 1). Available Cd levels in the soil increased with the use of MAP-S as compared to both the control and MAP-R, being due to the incorporation of higher amounts of $\mathrm{Cd}$ with this fertilizer into the soil. The increase in available Cd levels in the soil can be due to the formation of the soluble phosphate complex $\mathrm{CdHPO}_{4}$, as previously reported by Lindsay (1979) and Krishnamurti et al. (1999). Lambert et al. (2007) observed direct dependence of soil $\mathrm{Cd}$ level on the degree of fertilizer contamination with $\mathrm{Cd}$, as also confirmed in this study. Similar findings were obtained previously by $\mathrm{He}$ and Singh (1995) who gained increased levels of available Cd in the soil after treatment with MAP fertilizer having an increasing content of Cd of 2.7 to 12.52 $\mathrm{mg} \mathrm{kg}{ }^{-1}$. Mann et al. (2002) evaluated the effect of phosphorus fertilizers containing higher amounts of $\mathrm{Cd}$ on $\mathrm{Cd}$ levels in a number of soil types and found the concentration of available $\mathrm{Cd}$ in sandy loam soil to increase with increasing fertilizer rate, as opposed to sandy soils which exhibited no increase in available $\mathrm{Cd}$ levels regardless of the high rates of phosphorus fertilizers applied. Levi-Minzi and Petruzzelli (1984) found that MAP induces a decrease in adsorbed $\mathrm{Cd}$ in the soil, particularly in the soil having a lower amount of organic matter, whereas Bogdanovic et al. (1999) suggested that increasing rates 
of phosphorus fertilizers do not result in statistically significant changes in $\mathrm{Cd}$ concentration in chernozem soil.

The use of manure also increased available Cd levels in the soil as compared to the control. The results suggest that optimal manure application rates pose no risk of soil contamination with cadmium. However, the long-term use of increased rates of manure can cause an increase in available Cd levels for plants (Lipoth and Schoenau 2007; Benke et al. 2008). Ju et al. (2007) observed that soil Cd concentration increases only after treatment with enormously high rates of manure and phosphorus fertilization.

Table 3 - Analysis of variance of the tested parametres (ANOVA)

\begin{tabular}{|c|c|c|c|c|}
\hline \multicolumn{5}{|c|}{ Effect of soil types on the traits analyzed } \\
\hline Traits & $\begin{array}{l}\text { Mean sqr. } \\
\text { Effect }\end{array}$ & $\begin{array}{l}\text { Mean sqr. } \\
\text { Error }\end{array}$ & $\mathrm{F}$ & p-level \\
\hline Available $\mathrm{Cd}$ in the soil & .003971 & .000022 & 178.0862 & .000000 \\
\hline Cd concentration in lettuce & 243613 & .002628 & 92.71243 & .000000 \\
\hline Weight of lettuce head & 28981.50 & 216.3700 & 133.9442 & .000000 \\
\hline \multicolumn{5}{|c|}{ Effect of fertilization on the traits analyzed } \\
\hline Traits & $\begin{array}{l}\text { Mean sqr. } \\
\text { Effect }\end{array}$ & $\begin{array}{l}\text { Mean sqr. } \\
\text { Error }\end{array}$ & $\mathrm{F}$ & p-level \\
\hline Available $\mathrm{Cd}$ in the soil & .000073 & .000022 & 3.2783 & .048336 \\
\hline Cd concentration in lettuce & .053684 & .002628 & 20.43081 & .000010 \\
\hline Weight of lettuce head & 8200.00 & 216.3700 & 37.8980 & .000000 \\
\hline \multicolumn{5}{|c|}{ Effect of soil types $x$ fertilization on the traits analyzed } \\
\hline Traits & $\begin{array}{l}\text { Mean sqr. } \\
\text { Effect }\end{array}$ & $\begin{array}{l}\text { Mean sqr. } \\
\text { Error }\end{array}$ & $\mathrm{F}$ & p-level \\
\hline Available $\mathrm{Cd}$ in the soil & .000002 & .000022 & .0854 & 967035 \\
\hline Cd concentration in lettuce & .023212 & .002628 & 8.83402 & .001098 \\
\hline Weight of lettuce head & 85.50 & 216.3700 & .3952 & .758230 \\
\hline
\end{tabular}

Table 3 shows the impact of soil type, fertilization and ineraction of soil type $\mathrm{x}$ fertilization on available $\mathrm{Cd}$ in the soil, $\mathrm{Cd}$ concentration in lettuce and weight of lettuce head. The ANOVA indicated highly significant effects of the soil type and all tested parameters, and fertilization and Cd concentration in lettuce and weight of lettuce head. Highly significant differences in Cd concentration in lettuce were found in relation with ineraction of soil type $\mathrm{x}$ fertilization. Furthemore, available $\mathrm{Cd}$ in the soil was significantly affected by the fertilization. The interaction of available $\mathrm{Cd}$ in the soil and soil type $\mathrm{x}$ fertilization and interaction of weight of lettuce head and soil type $\mathrm{x}$ fertilization did not show statistical significant. 


\section{Cd concentration in lettuce}

Cd levels in lettuce grown on vertisol were between $0.437 \mathrm{mg} \mathrm{kg}^{-1} \mathrm{DM}$ and $0.515 \mathrm{mg} \mathrm{kg}^{-1} \mathrm{DM}$ and those on fluvisol ranged from $0.521 \mathrm{mg} \mathrm{kg}^{-1} \mathrm{DM}$ to 0.824 $\mathrm{mg} \mathrm{kg}^{-1} \mathrm{DM}$ (Figure 2). These values of Cd levels in lettuce fall within the values obtained on control agricultural soil by Sterret et al. (1996). In the present study, all treatments except manure application on vertisol resulted in increased $\mathrm{Cd}$ levels in lettuce as compared to the control (Figure 2). The results obtained can be attributed to the fact that lettuce has the affinity to uptake and accumulate $\mathrm{Cd}$; therefore, the plants accumulated $\mathrm{Cd}$ from the phosphorus fertilizers applied in the soil. Manure treatment on vertisol did not lead to an increase in Cd levels in lettuce, whereas that on fluvisol induced a slight increase as compared to the control, which was an expected occurrence, given the low Cd content of manure. Lipoth and Schoenau (2007) found that only long-term manure treatment can sometimes result in increased $\mathrm{Cd}$ availability to plants.

Nevertheless, high $\mathrm{Cd}$ accumulation was not found in lettuce since the applied phosphorus fertilizers were not significantly contaminated with $\mathrm{Cd}$. The differences observed in Cd levels in lettuce between MAP-S and MAP-R were directly induced by their different Cd content. Namely, the Cd content of MAP$\mathrm{R}$ was lower than that of MAP-S (Table 2) and, hence, lower amounts of this metal were introduced into the soil. Similar findings on increased Cd levels in lettuce resulting from increased $\mathrm{Cd}$ content of fertilizers were obtained by (Sterret et al. 1996; He and Singh 1995). Guttormsen et al. (1995) reported that increased rates of $\mathrm{Cd}$ applied through fertilizers induced an increase in Cd levels in the vegetable crop, with the differences being non-significant, as in the present study. Jiao et al. (2004) analyzed the effect of increasing Cd content of MAP and found an increase in Cd level in different parts of wheat. Mclaughlin et al. (1995) suggested that Cd concentration in potato tubers is affected by $\mathrm{Cd}$ content of phosphorus fertilizers, with residual $\mathrm{Cd}$ in the soil being the major source of its uptake. This study also showed significant correlation between $\mathrm{Cd}$ levels in lettuce and available $\mathrm{Cd}$ in the soil i.e. Cd uptake by the plant increased with increasing levels of available $\mathrm{Cd}$ in the soil. Similar results were reported by (Fontes et al. 2008; Chaudri et al. 2001). It is noteworthy that lettuce showed no symptoms of $\mathrm{Cd}$ excess in all treatments in this study. This suggests the ability of $\mathrm{Cd}$ to accumulate in lettuce without any visual proof of its presence as well as the fact that the $\mathrm{Cd}$ amounts introduced into the soil were not phytotoxic. 


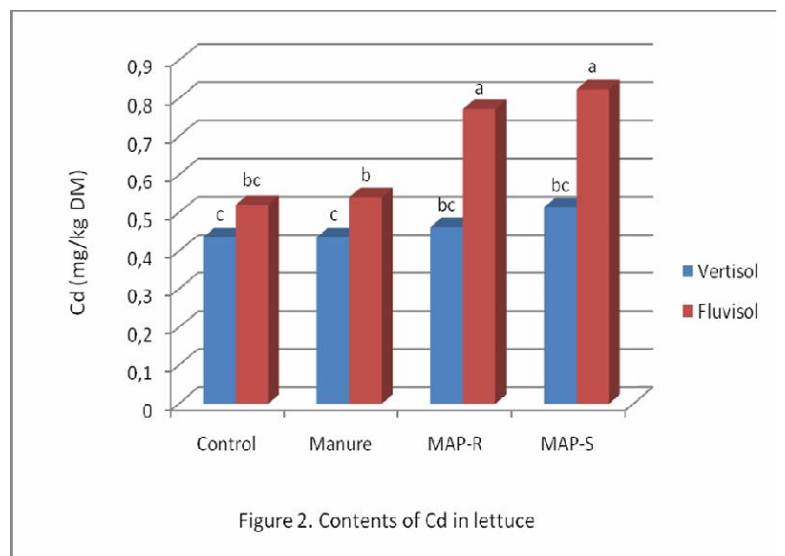
LSD test

\section{Weight of lettuce head}

The measured weight of lettuce head was lowest in the control (277 $\mathrm{g}$ on vertisol and $198 \mathrm{~g}$ on fluvisol, Figure 3). The highest weight of lettuce (356 $\mathrm{g}$ and $295 \mathrm{~g}$ on vertisol and fluvisol, respectively) was obtained with the use of manure, which suggests that manure as a complete organic fertilizer not only affects the soil nutrient regime but also acts as a soil amendment. Namely, manure improves soil structure, air and water relationships, thermal and microbial regimes of the soil, thereby enhancing the development of the root system and, hence, growth of lettuce head. In addition, the use of manure resulted in reduced $\mathrm{Cd}$ accumulation in lettuce and, thus, higher yield. Similar results were obtained by Qiang et al. (2009).

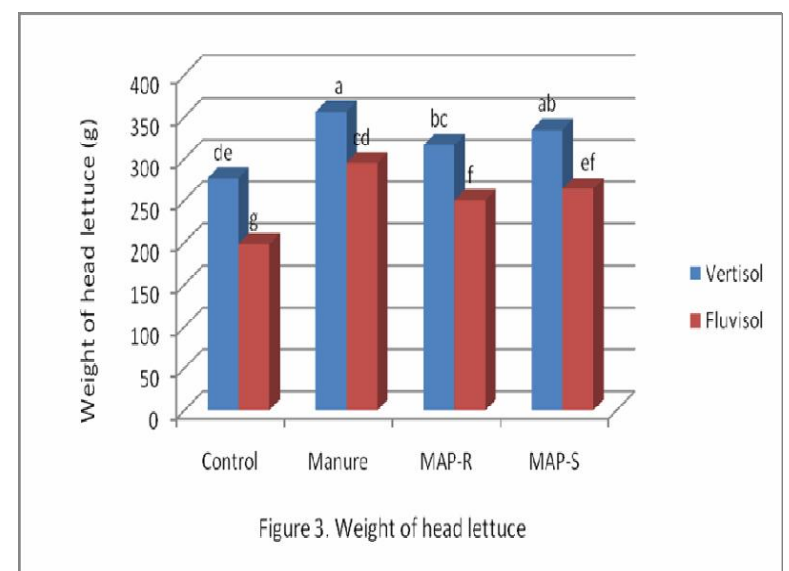

*The same letters indicate non-significant differences among means at $\mathrm{P} \leq 0.05$ by LSD test 
Phosphorus fertilization in both soils induced an increase in lettuce head weight relative to the control. A greater weight of lettuce head was obtained with MAP-S treatment as compared to MAP-R. The above results comply with those of Kavvadias et al. (2012) who found that increasing Cd application rates, up to a certain amount $\left(10 \mathrm{mg} \mathrm{kg}^{-1} \mathrm{Cd}\right)$, lead to an increase in fresh biomass as compared to the control, whereas further $\mathrm{Cd}$ additions reduce fresh biomass, although not to a significant level.

\section{Conclusion}

Treatment with MAP-R (Russian MAP) resulted in decreased Cd levels as compared to the control and manure in both soil types. After treatment with MAP-S (Serbian MAP), available Cd levels in vertisol and fluvisol increased non-significantly as compared to the control and manure, but statistically significantly as compared to MAP-R. All treatments, excepting manure on vertisol, gave increased $\mathrm{Cd}$ levels in lettuce as compared to the control. The $\mathrm{Cd}$ content of lettuce was lower after MAP-R treatment than after MAP-S treatment. The highest weight of lettuce (356 g on vertisol and $295 \mathrm{~g}$ on fluvisol) was obtained with the use of manure. A greater weight of lettuce head was obtained with MAP-S treatment as compared to MAP-R.

\section{Acknowledgements}

This work is part of the 31059 project financially supported by the Ministry of Education and Science of the Republic of Serbia.

\section{References}

Allen, S.E. (1989): Chemical analysis of ecological materials. Second ed. Blackwell Scientific Publications, Oxford.

Benke, M.B., Indraratne, S.P., Hao, X., Chang, C., Goh, T.B. (2008): Trace element changes in soil after long-term cattle manure applications. Journal of Environmental Quality, 37: 798-807.

Bogdanovic, D., Ubavic, M., Cuvardic, M. (1999): Effect of phosphorus fertilization on $\mathrm{Zn}$ and $\mathrm{Cd}$ contents in soil and corn plants. Nutrient Cycling in Agroecosystems, 54: 49-56.

Chaudri, A.M., Allain, C.M.G., Badawy, S.H., Adam, M.L., McGrath, S.P., Chambers, B.J. (2001): Cadmium content of wheat grain from a long-term field experiment with sewage sludge. Journal of Environmental Quality, 30: 1575-1580. 
Chen, W., Li, L., Chang, A.C., Wu, L., Kwon, S., Bottoms, R. (2009): Cadmium uptake by lettuce in fields treated with cadmium-spiked phosphorus fertilizers. Communications in Soil Science and Plant Analysis, 40: 1124-1137.

Fallovo, C., Rouphael, Y., Rea, E., Battistelli, A., Colla, G. (2009): Nutrient solution concentration and growing season affect yield and quality of Lactuca sativa L. var. acephala in floating raft culture. Journal of the Science of Food and Agriculture, 89(10): 1682-1689.

Fontes, R.L.F., Pereira, J.M.N., Neves, J.C.L., Fontes, M.P.F. (2008) : Cadmium, lead, cooper, zinc and nickel in lettuce and dry beans as related to mehlich-3 extraction in three brazilian latossols. Journal of Plant Nutrition, 31: 884901.

Golia, E.E., Dimirkou, A., Mitsios, I.K. (2008): Influence of some soil parameters on heavy metals accumulation by vegetables grown in agricultural soils of different soil orders. Bulletin of environmental contamination and toxicology, 81: 8084.

Guttormsen, G., Singh, B.R., Jeng, A.S. (1995): Cadmium concentration in vegetable crops grown in a sandy soil as affected by $\mathrm{Cd}$ levels in fertilizer and soil $\mathrm{pH}$. Nutrient Cycling in Agoecosystems, 41: 27-32.

He, Q.B., Singh, B.R. (1994): Crop uptake of cadmium from phosphorus fertilizers: I. Yield and cadmium content. Water, Air \& Soil Pollution, 74: 251-265.

He, Q.B., S ingh, B.R. (1995): Cadmium availability to plants as affected by repeated applications of phosphorus fertilizers. Acta Agriculturae Scandinavica, Section B-Soil \& Plant Science, 45: 22-31.

Jiao, Y., Grant, C.A., Bailey, L.D. (2004): Effects of phosphorus and zink fertilizer on cadmium uptake and distribution in flax and durum wheat. Journal of the Science of Food and Agriculture, 84: 777-785.

John, R., Ahmad, P., Gadgil, K., Sharma, S. (2008): Effect of cadmium and lead on growth, biochemical parameters and uptake in Lemna polyrrhiza L. Plant Soil Environment, 54: 262-270.

Ju, X.T., Kou, C.L., Christie, P., Dou, Z.X., Zhang, F.S. (2007): Changes in the soil environment from excessive applications of fertilizers and manures to two contrasting intensive cropping systems on the North China Plain. Environmental Pollution, 145: 497-506.

Kavvadias, V., Paschalidis, C., Vavoulidou, E., Petropoulos, D., Koriki, A. (2012): Effects of soil amended with cadmium and lead on growth, yield and metal accumulation and distribution in parsley. Communications in Soil Science and Plant Analysis, 43: 161-175.

Krishnamurti, G.S.R., Huang, P.M., Kozak, L.M. (1999): Sorption and desorption kinetics of cadmium from soils: influence of phosphate. Soil Science, 164: 888-898.

Lambert, R., Grant, C., Sauvé, S . (2007): Cadmium and zinc in soil solution extracts following the application of phosphate fertilizers. Science of the Total Environment, 378: 293-305.

Levi-Minzi, R., Petruzzelli, G. (1984): The influence of phosphate fertilizers on Cd solubility in soil. Water, Air \& Soil Pollution, 23: 423-429. 
Lindsay, W.L., Norve11, W.A. (1978): Development of a DTPA soil test for zinc, iron, manganese and copper. Soil Science Society of America Journal, 42: 421428.

Lindsay, W.L. (1979): Chemical equilibria in soils. Wiley-Interscience publication, John Wiley \& Sons, New York.

Lipoth, S.L., Schoenau, J.J. (2007): Copper, zinc and cadmium accumulation in two prairie soils and crops as influenced by repeated applications of manure. Journal of Plant Nutrition and Soil Science, 170: 378-386.

Maclean, A.J. (1976): Cadmium in different plant species and its availability in soils as influenced by organic matter and additions of lime, P, Cd and $\mathrm{Zn}$. Canadian Journal of Soil Science, 56: 129-138.

Mann, S.S., Rate, A.W., Gilkes, R.J. (2002): Cadmium accumulation in agricultural soils in western Australia. Water, Air \& Soil Pollution, 141: 281-297.

McLaughlin, M.J., Majer, N.A., Freeman, K., Tiller, K.G., Williams, C.M.J., Smart, M.K. (1995): Effect of potassic and phosphatic fertilizer type, fertilizer $\mathrm{Cd}$ concentration and zinc rate on cadmium uptake by potatoes. Nutrient Cycling in Agroecosystems, 40: 63-70.

Moustakas, N.K., Akoumianakis, K.A., Passam, H.C. (2001): Cadmium accumulation and its effect on yield of lettuce, radish and cucumber. Communications in Soil Science and Plant Analysis, 32: 1793-1802.

Nels on, D.W., S o mmers, L.E. (1982): Total carbon, organic carbon, and organic matter. In: Page AL, editor. Methods of soil analysis, Part 2 (2nd), Madison, WI: American Society of Agronomy.

Qiang, L.Z., Fen, X.J., Fang, M.Q., Peng, Y.M., Fei Z. (2009): Effects of organic manure and lime on growth and heavy metal accumulation in Alfalfa grown in soil polluted by lead/zinc mine tailings. Guangxi Agricultural Sciences, 40: 1187-1191.

Sani, H.A., Tsafe, A.I., Bagudo, B.U., Itodo, A.U. (2011): Toxic metal uptake by spinach (Spinacea oleracea) and lettuce (Lactuca sativa) cultivated in Sokoto: Comparative study. Pakistan Journal of Nutrition, 10: 572-576.

Singh, B.R., (1990): Uptake of cadmium and fluoride by oat from phosphate fertlizers. Norwegian Journal of Agricultural Sciences, 4: 239-249.

Sterrett, S.B., Chaney, R.L., Gifford, C.H., Mielke, H.W. (1996): Influence of fertilizer and sewage sludge compost on yield and heavy metal accumulation by lettuce grown in urban soil. Environmental Geochemistry and Health, 18: 135-142.

Williams, C.H., David, D.J. (1973): The effect of superphosphate on the cadmium content of soils and plants. Australian Journal of Soil Research, 11: 43-56.

Zheng, G., Lv, H.P., Gao, S., Wang, S.R. (2010): Effects of cadmium on growth and antioxidant responses in Glycyrrhiza uralensis seedlings. Plant Soil Environment, 56: 508-515. 


\title{
UTICAJ ĐUBRENJA NA SADRŽAJ PRISTUPAČNOG KADMIJUMA U ZEMLJIŠTU I ZELENOJ SALATI
}

\author{
Ljiljana Bošković-Rakočević, R. Pavlović \\ Univerzitet u Kragujevcu, Agronomski fakultet u Čačku
}

Darinka Bogdanović

Univerzitet u Novom Sadu, Poljoprivredni fakultet, Novi Sad

\section{Rezime}

Cilj ovih istraživanja je bio da se ispita uticaj organskog đubriva (stajnjaka) $\mathrm{i}$ monoamonijum fosfata (ruski MAP-R i srpski MAP-S) na sadržaj pristupačnog $\mathrm{Cd} \mathrm{u}$ zemljištu i usvajanje $\mathrm{Cd}$ od strane zelene salate, gajene na vertisolu i fluvisolu. Tretmani đubrenja su bili sledeći: kontrola - bez đubrenja, stajnjak (20 $\mathrm{g} \mathrm{kg}^{-1}$ zemljišta), MAP-R $\left(0,1 \mathrm{~g} \mathrm{~kg}^{-1}\right.$ zemljišta), MAP-S $\left(0.1 \mathrm{~g} \mathrm{~kg}^{-1}\right.$ zemljišta). Pre eksperimenta, sadržaj pristupačnog Cd je bio veći u vertisolu $\left(0.06 \mathrm{mg} \mathrm{kg}^{-1}\right)$ nego $\mathrm{u}$ fluvisolu $\left(0.04 \mathrm{mg} \mathrm{kg}^{-1}\right)$. Primena stajnjaka nije imala značajan uticaj na povećanje sadržaja DTPA - pristupačnog Cd kod oba tipa zemljišta, u odnosu na kontrolu. Sadržaj pristupačnog $\mathrm{Cd}$ je smanjen primenom MAP-R (vertisol $0.0494 \mathrm{mg} \mathrm{kg}^{-1}$, fluvisol $0.0227 \mathrm{mg} \mathrm{kg}^{-1}$ ) i povećan primenom MAP-S (vertisol $0.0577 \mathrm{mg} \mathrm{kg}^{-1}$, fluvisol $0.0288 \mathrm{mg} \mathrm{kg}^{-1}$ ) kod oba tipa zemljišta, u odnosu na kontrolu. Upotreba stajnjaka i MAP je povećala koncentraciju Cd u salati u svim tretmanima, osim kod primene stajnjaka na vertisolu. Masa glavice salate je bila najveća primenom stajnjaka na oba tipa zemljišta.

Ključne reči: pristupačni $\mathrm{Cd}$, stajnjak, fosforna đubriva, fluvisol, vertisol 